\title{
Distribution of ABO, Rh Blood Grouping and Hepatitis B Among Blood Donors With Blood Transfusion Service In Federal Medical Centre, Owo, Ondo State Nigeria
}

\author{
Oke T. $\mathrm{O}^{1}$, Obeagu Emmanuel Ifeanyi ${ }^{1},{ }^{2 *}$, Adekunle Joke Mary ${ }^{1}$, Hassan A. $\mathrm{O}^{1}$ \\ ${ }^{1}$ Department of Medical Laboratory Science, Achievers University, Owo, Ondo State, Nigeria \\ ${ }^{2}$ Department of Medical Laboratory Science, Imo State University, Owerri, Nigeria
}

DOI: $10.36348 /$ sb.2020.v06i12.002

| Received: 25.11.2020 | Accepted: 18.12.2020 | Published: 30.12.2020

*Corresponding author: Obeagu Emmanuel Ifeanyi

\section{Abstract}

The study was done to determine distribution and frequencies of $\mathrm{ABO}$ and $\mathrm{Rh}$ blood groups among blood donors and to establish the existence or widespread of this hepatitis B virus among this group of people in FMC Owo. The study was carried out in Owo and the analysis of the samples was done in the Department of Haematology and Blood Bank, Federal Medical Centre, Owo, Ondo State. After an informed consent was obtained 120 blood donors (110 male and 10 females) volunteered to participate in the exercise. Demographic data forms which carried all the information, personal details such as occupation, educational back ground, age, sex, medical history e.t.c were filled by each donor. All the donors were apparently healthy, age 18 to 60 years with body weight $50 \mathrm{~kg}$. About $5 \mathrm{ml}$ of blood was collected from each donor with the donor in a sitting position. The blood was transferred into plain bottles and allowed to clot, centrifuged at $1500 \mathrm{rpm}$ for 3 minutes to obtain serum. The serum samples were transferred to vials for use and preserved at $-20 \mathrm{C}$ until use. $\mathrm{ABO}$ and $\mathrm{Rh}$ grouping were determined using tiles methods by the agglutination of red cell in the presence of the corresponding antigen after a drop of antisera was placed on a clean tile. Hepatitis B surface antigen was determined by the Rapid Response TM Hepatitis B Surface Antigen (HBsAg) test strip. Simple percentage distributions and tables were used to represent the results. Phenotypic frequencies were calculated and expressed as percentage. Table- 1 shows the age distribution and ABO blood group among various occupations of 120 subjects that participated in the research. The artisans were 26(12.6) with their age range 31-40. Their ABO blood group number and their percentages were as follow: A 2(1.66), B 5(4.17), AB 1(0.83) and $\mathrm{O} 8(5)$. Other groups of people \% frequency, age range and ABO distributions were as shown in the table. Table-2 shows the occurrence of hepatitis B virus among the various groups of people that participated in this project work. The total number of people that were positive and negative and their percentages were 13(10.83) and 107(89.17). Artisans group showed the highest number 6(5) and Civil servants were the group with the least number 1(0.83). The ABO, rhesus (D) blood group and Hepatitis B virus distribution among the Owo blood donors were shown in Table-3. Out of the 120 donors only 4(3.3\%) were rhesus (D) negative belonging to blood ABO blood group $\mathrm{O}$. Other $\mathrm{ABO}$ blood groups were rhesus (D) positive. Blood group $\mathrm{O}$ also has the highest number of hepatitis $\mathrm{B}$ virus 13(10.9) while $\mathrm{AB}$ has the least (0). The Government should intensify and encourage the artisan to surrender themselves to be immunized against HBsAg and also encourage the adults to participate in voluntary blood donation in order to safe life.

Keywords: Distribution, ABO, Rh blood grouping, hepatitis B, blood donors, blood transfusion service, Federal Medical Centre, Owo.

Copyright (C) 2020 The Author(s): This is an open-access article distributed under the terms of the Creative Commons Attribution 4.0 International License (CC BY-NC 4.0) which permits unrestricted use, distribution, and reproduction in any medium for non-commercial use provided the original author and source are credited.

\section{INTRODUCTION}

Blood is defined as the red viscous fluid that circulates round the body supplying $\mathrm{O} 2$ and nutritive substances absorbed from the gastrointestinal tract to the tissues, return $\mathrm{CO} 2$ to the lungs and other products of metabolism to the kidneys, functions in the regulation of body temperature, and distribute hormones and other agents that regulate cell function. The most famous blood groups are those of $\mathrm{ABO}$ and Rhesus ( $\mathrm{Rh})$ series [1]. The ABO blood group are the first red cell antigens while the Rhesus blood group are the most immunogenic red cell antigens discovered. Both are routinely typed for in any blood bank or blood 
transfusion service [2]. Blood-group antigens may be carbohydrate structures on red cell surface glycoproteins or glycolipids [3], or they may be determined primarily by the amino acid sequence of polypeptides or glycoproteins [4]. At least 23 red cell surface proteins express blood-group polymorphism [5]. The ABO blood group system of carbohydrate antigen expression on the surface of human red blood cells (RBCs) was first described by Karl Landsteiner in 1900 and represented an important step towards development of safer blood transfusions. Alfred von Decastello and Adriano Sturli discovered the 4th type, AB, in 1902 [6] while Landsteiner and Weiner in 1940 discovered the Rhesus (Rh) blood group (Iyiola et al., 2011). Based on RBC agglutination patterns, individuals could be divided into 4 major groups $\mathrm{A}, \mathrm{B}, \mathrm{AB}$, and $\mathrm{O}$. $\mathrm{ABO}$ and Rhesus ( $R$ h) blood group antigens are hereditary characters and are useful in population genetic studies, researching population migration patterns, as well as resolving certain medicolegal issues, particularly of disputed paternity and more importantly in compatibility test in blood transfusion practice [7]. The ABO blood group gene is known to code for a glycosyltransferase, which acts at the last step of sequential extension of oligosaccharide chains attached to glycoproteins or glycolipids [4]. The Rh blood group is named for the rhesus monkey, in which the $\mathrm{Rh}$ antigens were discovered in 1940. It is the most complex of the human blood-group systems with 52 well-defined antigens, the most immunogenic of which is $\mathrm{D}$ (RHD) [5]. The $\mathrm{Rh}$ blood groups rank with $\mathrm{ABO}$ groups in clinical importance because of their relation to haemolytic disease of the newborn (HDN) and their importance in blood transfusion [8]. The $\mathrm{Rh}$ is genetically complex but it is simply described in terms of a single pair of alleles, D and $\mathrm{d}$ This group is determined by three genes called C, D, and E, each of which has two alleles: C, c, D, dE, e. The Rh blood type is tested by using an anti-D reagent [5]. Rh frequencies vary among ethnic groups just as $\mathrm{ABO}$ frequencies. Between $82 \%$ and $88 \%$ of Caucasians, about $95 \%$ of black Africans, and almost $100 \%$ of people from the Far East are D-positive [9]. In contrast to the ABO group, anti-D antibodies are not normally present in the blood. They form only in Rh-individuals who are exposed to $\mathrm{Rh}+$ blood [10]. The antigens of the Rh system are encoded by two genes, RHD and RHCE. They are highly homologous and have very similar genomic organization, each containing 10 coding exons arranged in opposite orientation on chromosome 1.

The viral particle consists of an outer lipid envelope and an icosahedral nucleocapsid core which is composed of protein. The outer envelope contains proteins that are involved in viral binding and entry into susceptible cells. WHO [11] posited that people at high risk include prison inmates, IDUs, people who frequently require blood and blood products, mentally ill persons, people with multiple sexual partners and health-care workers. The virus is found in body fluids and blood and it is transmitted from person to person through sex, tattooing, body piercing with unsterilized equipment, sharing of equipment like razor, toothbrush and IDU. Blood transfusion service (BTS) is an integral and indispensable part of the healthcare system. The priority objective of BTS is to ensure safety, adequacy, accessibility, and efficiency of blood supply at all levels [12]. Transfusion of blood and blood components, as a specialized modality of patient management saves millions of lives worldwide each year and reduces morbidity. It is well known that blood transfusion is associated with a large number of complications, some are only trivial and others are potentially life threatening, demanding for meticulous pretransfusion testing and screening. The use of unscreened blood transfusion keeps the patient at risk of acquiring many transfusion transmitted infections (TTI) like hepatitis viruses (HBV, HCV), human immuno-deficiency viruses (HIV), syphilis, malaria, etc. Transfusion departments have always been a major portal to screen, monitor, and control infections transmitted by blood transfusion. Blood transfusion departments do not only screen TTI, but also give clue about the prevalence of these infections in healthy populations [13]. Hepatitis B virus (HBV) infection is a serious global health problem affecting 2 billion people world-wide and 350 million people suffer from chronic HBV infection [14]. HBV is highly infectious and can be transmitted transmitted covertly by percutaneous routes and overtly by blood transfusion [15].

The aim of this work was to determine distribution and frequencies of $\mathrm{ABO}$ and $\mathrm{Rh}$ blood groups among blood donors and to establish the existence or widespread of this hepatitis B virus among this group of people in FMC Owo.

\section{MATERIALS AND METHOD Study Area}

The study was carried out in Owo and the analysis of the samples was done in the Department of Haematology and Blood Bank, Federal Medical Centre, Owo, Ondo State.

\section{Study Design}

It is a retrospective study that was carried out at Federal Medical Centre Owo Blood Bank.

\section{Subjects}

After an informed consent was obtained 120 blood donors (110 male and 10 females) volunteered to participate in the exercise. Demographic data forms which carried all the information, personal details such as occupation, educational back ground, age, sex, medical history e.t.c were filled by each donor. All the donors were apparently healthy, age 18 to 60 years with body weight $50 \mathrm{~kg}$. 
Oke T. O et al., Sch Bull, Dec, 2020; 6(12): 257-261

\section{Inclusion criteria}

Voluntary blood donors (altruistic donations) and the replacement blood donors (blood donated to replace blood utilized, and often includes friends or relatives of patients).

\section{Exclusion criteria}

Donors with any form of illness and those that do not conform to the standard criteria set out for blood donation

\section{Sample collection and storage}

About $5 \mathrm{ml}$ of blood was collected from each donor with the donor in a sitting position. The blood was transferred into plain bottles and allowed to clot, centrifuged at 1500 rpm for 3 minutes to obtain serum. The serum samples were transferred to vials for use and preserved at $-20 \mathrm{C}$ until use.

\section{Laboratory procedures}

$\mathrm{ABO}$ and $\mathrm{Rh}$ typing was done using the tile method. A drop of blood was placed and a drop of anti $\mathrm{A}$, anti $\mathrm{B}$, anti $\mathrm{AB}$ and anti $\mathrm{D}$ blood group sera was applied, it was mixed by means of an applicator stick. It was rocked gently and was observed for agglutination. Presence of agglutination indicates the presence of the corresponding blood group.

For the hepatitis B test the blood was centrifuged at $1500 \mathrm{rpm}$ for $3 \mathrm{~min}$ to obtain serum. The serum samples were transferred to vials and were preserved at $20^{\circ} \mathrm{C}$ until use. After Centrifugation few drops of serum was added on the Rapid Response TM
Hepatitis B Surface Antigen (HBsAg) Test Strip. It was left for 5 mins and was observed.

\section{Ethical considerations}

Ethical approval was obtained from Ethical and Research committee, Federal Medical Centre, Owo.

\section{Analytical methods and procedures}

1. $\mathrm{ABO}$ and $\mathrm{Rh}$ grouping were determined using tiles methods by the agglutination of red cell inthepresenceofthecorrespondingantigenafteradrop ofantiserawasplacedonacleantile

2. Hepatitis B surface antigen was determined by the Rapid Response TM Hepatitis B Surface Antigen (HBsAg) test strip.

\section{Statistical Analysis}

Simple percentage distributions and tables were used to represent the results. Phenotypic frequencies were calculated and expressed as percentage.

\section{RESULT}

Table-1 shows the age distribution and $\mathrm{ABO}$ blood group among various occupations of 120 subjects that participated in the research. The artisans were 26(12.6) with their age range 31-40. Their ABO blood group number and their percentages were as follow: A 2(1.66), B 5(4.17), AB 1(0.83) and $\mathrm{O} 8(5)$. Other groups of people \% frequency, age range and $\mathrm{ABO}$ distributions were as shown in the table.

Table-1: ABO Distribution and Age Distribution among various occupations

\begin{tabular}{|l|l|l|l|l|l|l|}
\hline OCCUPATION & $\begin{array}{l}\text { FREQUENCY } \\
(\boldsymbol{\%})\end{array}$ & AGE & $\begin{array}{l}\text { BLOOD } \\
\text { GROUP A } \\
(\boldsymbol{\%})\end{array}$ & $\begin{array}{l}\text { BLOOD } \\
\text { GROUP } \\
(\boldsymbol{\%})\end{array}$ & $\begin{array}{l}\text { BLOOD } \\
\text { GROUP AB } \\
(\boldsymbol{\%})\end{array}$ & $\begin{array}{l}\text { BLOOD } \\
\text { GROUP O } \\
(\boldsymbol{\%})\end{array}$ \\
\hline ARTISANS & $26(21.6)$ & $31-40$ & $2(1.66)$ & $5(4.17)$ & $1(0.83)$ & $18(15)$ \\
\hline $\begin{array}{l}\text { CIVIL } \\
\text { SERVANTS }\end{array}$ & $11(9.2)$ & $41-49$ & $2(1.66)$ & $2(1.66)$ & $1(0.83)$ & $6(5)$ \\
\hline STUDENTS & $50(41.7)$ & $19-24$ & $3(2.5)$ & $1(0.83)$ & $0(0)$ & $46(38.3)$ \\
\hline OTHERS & $33(27.5)$ & $25-30$ & $2(1.66)$ & $2(1.66)$ & $0(0)$ & $29(24.2)$ \\
\hline TOTAL & $120(100)$ & & $9(7.51)$ & $10(8.33)$ & $2(1.66)$ & $99(82.5)$ \\
\hline
\end{tabular}

Table-2 shows the occurrence of hepatitis B virus among the various groups of people that participated in this project work. The total number of people that were positive and negative and their percentages were 13(10.83) and 107(89.17). Artisans group showed the highest number 6(5) and Civil servants were the group with the least number 1(0.83).

Table-2: Hepatitis B Distribution and Age Distribution among various occupations

\begin{tabular}{|l|l|l|l|l|}
\hline OCCUPATION & $\begin{array}{l}\text { FREQUENCY } \\
(\boldsymbol{\%})\end{array}$ & AGE & $\begin{array}{l}\text { HEPATITIS B } \\
\text { POSITIVE (\%) }\end{array}$ & $\begin{array}{l}\text { HEPATITIS B } \\
\text { NEGATIVE (\%) }\end{array}$ \\
\hline ARTISANS & 26 & $31-40$ & $6(5)$ & $20(16.67)$ \\
\hline CIVIL SERVANTS & 11 & $41-49$ & $1(0.83)$ & $10(8.33)$ \\
\hline STUDENTS & 50 & $18-24$ & $3(2.5)$ & $47(39.17)$ \\
\hline OTHERS & 33 & $25-30$ & $3(2.5)$ & $30(25)$ \\
\hline TOTAL & 120 & & $13(10.83)$ & $107(89.17)$ \\
\hline
\end{tabular}


Oke T. O et al., Sch Bull, Dec, 2020; 6(12): 257-261

The ABO, rhesus (D) blood group and Hepatitis B virus distribution among the Owo blood donors were shown in table 3 . Out of the 120 donors only $4(3.3 \%)$ were rhesus (D) negative belonging to blood ABO blood group O. Other ABO blood groups were rhesus (D) positive. Blood group $\mathrm{O}$ also has the highest number of hepatitis $B$ virus $13(10.9)$ while $A B$ has the least $(0)$.

Table-3: Shows the ABO, Rhesus and Hepatitis B virus and their \% distribution among blood donors in Owo

\begin{tabular}{|l|l|l|l|l|}
\hline $\begin{array}{l}\text { ABO Blood } \\
\text { group }\end{array}$ & $\begin{array}{l}\text { Rhesus 'D' Positive } \\
(\boldsymbol{\%})\end{array}$ & $\begin{array}{l}\text { Rhesus 'D' Negative } \\
(\boldsymbol{\%})\end{array}$ & $\begin{array}{l}\text { HbsAg Positive } \\
(\boldsymbol{\%})\end{array}$ & $\begin{array}{l}\text { HbsAg } \\
\text { Negative( } \%)\end{array}$ \\
\hline A & $9(7.5)$ & $0(0)$ & $2(1.7)$ & $7(5.8)$ \\
\hline B & $10(8.3)$ & $0(0)$ & $2(1.7)$ & $8(6.6)$ \\
\hline AB & $2(1.7)$ & $0(0)$ & $0(0)$ & $2(1.7)$ \\
\hline O & $95(79.2)$ & $4(3.3)$ & $9(7.5)$ & $90(75)$ \\
\hline TOTAL & $116(96.7)$ & $4(3.3)$ & $13(10.9)$ & $107(89.1)$ \\
\hline
\end{tabular}

\section{DISCUSSION}

This study determined the distribution of $\mathrm{ABO}, \mathrm{Rh}$ antigens and hepatitis $\mathrm{B}$ among blood donors in FMC Owo. The current study showed that the majority of donors were male, which is consistent with other studies in Nigeria and in most regions in Africa [16]. One contributing factor might be that women do not meet donation cut-off values for hemoglobin given normal menses, menorrhagia, prenatal iron deficiency anemia and postnatal blood loss. From a cultural perspective, in various African countries it may be more likely for males to donate blood given long-standing beliefs that women are not as physically strong as men [17]. In Western regions such as Europe, women were found to have higher rates of adverse reactions, primarily vasovagal events, and were also not as likely to meet hemoglobin cut off requirements for donation [18].

The majority of donors in our study were replacement $(90 \%)$ while the minorities were voluntary $(10 \%)$. This is consistent with other studies and global trend [19]. WHO recommend $100 \%$ voluntary blood donation in other to create room for health systems 2017. The predominant blood group in the study was type $\mathrm{O}$ and the least common was $\mathrm{AB}$. These findings are comparable to that of similar studies by Hassan et al., [20] and Kulkarni et al., [21] in Northern Nigeria. Bashwari in Saudi Arabia and Manoharan in Malaysia also had similar findings with this study [6]. Determination of Rh status is crucial in clinical contexts in order to ensure patient safety. Rh factor is of interest because of its marked immunogenicity [22]. In the case of the D antigen, patients who do not produce the D antigen will produce anti-D if they encounter the D antigen on transfused red blood cells. This process may result in a hemolytic transfusion reaction or, in the case of newborn red blood cells, hemolytic disease of the newborn. For this reason, it is important to determine the $\mathrm{Rh}$ status in clinical settings and for research purposes. Individuals who are Rhesus negative in our study were only $3.3 \%$ in contrast to other studies, which showed a range between 5 and 17\% [23]. Our study showed a slightly lower prevalence of Rh positive blood donors (79.2) in comparison to other studies (In Uganda
Twenty-three thousand five hundred four $(23,504)$ blood donors were included in the study. The distribution of $\mathrm{ABO}$ blood group was; blood group $\mathrm{O}$ $(50.3 \%)$; blood group $\mathrm{B}(24.6 \%)$; blood group $\mathrm{A}$ $(20.7 \%)$ and blood group $\mathrm{AB}(4.5 \%)$. The proportions of Rhesus (D) positive and Rhesus (D) negative were 98 and 2\% respectively) [16] as well as in comparison with global trends. Given the number of participants in this study, however, this cannot be said to be statistically significant. When the distribution of both $\mathrm{ABO}$ and $\mathrm{Rh}$ blood groups system was considered, we found the top five blood groups, in descending order, to be; O Rh-positive, B Rh-positive, A Rh-positive, O Rhnegative and $\mathrm{AB}$ Rh-positive. These observations are in agreement with that of Ojo et al., [24]. Manoharan findings were also almost similar to ours except in their finding of B Rh-negative as the fifth most common blood group [25].

The overall distribution and prevalence of HBsAg was $10.9 \%$ in this study and prevail among the artisans who are blood group O.These observations are in agreement with that of Salawu et al., [26]. Mustapha and Jibrin [27] also record almost similar results where blood group $\mathrm{O}$ had the highest percentage of $\mathrm{HBsAg}$ and blood group $\mathrm{AB}$ was the least. The profile of HBsAg positive donors found in this study may be partially explained by the fact that majority of the people in this group are mechanics, panel betters, fashion designers and metalworkers where they were expose to various degree of injuries and their life styles may be a contributing factors. The prevalence of HBsAg positive among the civil servants was the least, this imply that the level of awareness and the knowledge of $\mathrm{HBsAg}$ is more among this group of people in Owo compared to other group. This study also reveals that students are more willing and ready to be voluntary donor compare to other group of people in Owo.

\section{CONCLUSION}

The Government should intensify and encourage the artisan to surrender themselves to be immunized against HBsAg and also encourage the 
adults to participate in voluntary blood donation in order to safe life.

\section{REFERENCES}

1. Khan, M. N., Khaliq, I., Bakhsh, A., Akhtar, M. S., \& Din, M. (2009). Distribution of ABO and $\mathrm{RhD}$ blood groups in the population of Poonch district. Eastern Mediterranean Health Journal. 15(3):717-720.

2. Bakare, A. A., Azeez, M. A., \& Agbolade, J. O. (2016). Gene frequencies of $\mathrm{ABO}$ and rhesus blood groups and haemoglobin variants in Ogbomosho, South-West Nigeria. African. Journal of Biotechnology, 5: 224-229.

3. Storry, J.R. and Olsson, M.L. (2014). Genetic basis of blood group diversity, British Journal of Haematology, 126:759-771.

4. Suzuki, K. (2015). ABO blood group alleles and genetic recombination, Legal Medicine, 7:205212.

5. Daniels, G. (2012). Human blood groups. Blackwell Science, 2nd edition Oxford.

6. Eweidah, M., Rahiman, S., Ali, H., \& AlShamary, A. (2011). Distribution of ABO and Rhesus ( $\mathrm{RhD}$ ) blood groups in Province of the Saudi Arabia Anthropologist; 13(2):99-102.

7. Enosolease, M. E., \& Bazuaye, G. N. (2008). Distribution of $\mathrm{ABO}$ and Rh-D blood groups in the Benin area of Niger-Delta: Implication for regional blood transfusion. Asian Journal of Transfusion Science, 2(1):3-5.

8. Adeyemo, O. A., \& Soboyejo, O. B. (2009). Frequency distribution of $\mathrm{ABO}, \mathrm{Rh}$ blood groups and blood genotypes among the cell biology and genetics students of University of Lagos, Nigeria. African Journal of Biotechnology, 5(22):20622065.

9. Iyawe, V. I., Igboroye, A. D., \& Akinyabi, G. A. (2009). Prelimnary survey of Rhesus inheritance and $\mathrm{ABO}$ blood groups in Nigerians. Nigeria Journal of Physiological Sciences. 15:18-9.

10. Saladin, K. (2013). Anatomy \& Physiology: The unity of form and function, Third Edition, The McGraw-Hill Companies, USA.

11. World Health Organization. (2013). Transfusion Medicine. Technical Manual, 2nd Edition. 151.

12. Islam, M. B. (2009). Blood transfusion services in Bangladesh. Asian Journal Transfusion Science. 3:108-110.

13. Khan, Z. T, Asim, S., Tariz, Z., Ehsan, I. A., Malik, R. A., \& Ashfaq. (2009). Prevalence of Hepatitis B virus in healthy blood donors. International Journal Pathology. 5:21-25.

14. Dhawan, H. K., Marwaha, N., Sharma, R. R., Chawla, Y., Thakral, B., Saluja, K., ... \& Jain, A. (2008). Anti-HBc screening in Indian blood donors: still an unresolved issue. World journal of gastroenterology: WJG, 14(34), 5327.

15. Karandeep, S., Sudha, B., \& Shamee, S. (2009). Trend in seroprevalence of Hepatitis B virus infection among blood donors of coastal Karnataka, India Journal Infections in Developed Countries. 3(5):376-379.

16. Tagny, C. T., Owusu-Ofori, S., Mbanya, D., \& Deneys, V. (2010). The blood donor in subSaharan Africa: a review of Transfusion Medicine. 20:1-10.

17. Mollison, P. L. (2014). The genetic basis of the Rh blood group system Transfusion. 34:539-41.

18. Patel, P. (2011). Frequency and distribution of blood groups in blood donors in western Ahmedabad-a hospital based study.

19. Pramanik, T., \& Pramanik, S. (2011). Distribution of $\mathrm{ABO}$ and $\mathrm{Rh}$ blood groups in Nepalese medical students: a report. East Mediterranean Health Journal. 6:156-8.

20. Hassan, A. W., Aliyu, S. A., \& Gashau, W. (2017). Distribution of ABO, RH (rhesus) blood grouping and hepatitis $\mathrm{B}$ among blood donors in national blood transfusion service Kaduna. Nigeria Journal Medicine. 9:10-12.

21. Kulkarni, A. G., Peter, B., Ibazebor, D. Z., \& Fleming, A. F. (2015). The ABO and Rhesus groups in the north of Nigeria. Annuals of Tropical Medicine and Parasitology. 79:83-8.

22. Mbalibulha, Y., Muwanguzi, E., Mugyenyi, G. R., \& Natukunda, B. (2015). Occurrence of anti-D alloantibodies among pregnant women in Kasese District, Western Uganda. Journal Blood Medicine. 6:125-9.

23. Mollison, P. L., Engelfriet, C. P., \& Conteras, M. (2010).The Rh blood group system. In Blood transfusion in clinical medicine 9th Edition. Oxford: Black well Scientific Publication; 2008-9.

24. Ojo, G. O., Ajose-Clokes, O. O., \& Balogun, O. O. (2017). Frequency distribution of ABO and Rhesus blood groups in the Urban population of Lagos. Conference Proceedings in Nigeria Journal of Physiological Sciences. 3:79-83.

25. Talukder, S., \& Das, R. (2010). Distribution of $\mathrm{ABO}$ and $\mathrm{Rh}$ blood groups among blood donors of Dinajpur district of Bangladesh. Dinajpur Medical College Journal. 3:55-8.

26. Salawu, L., Adegoke, A. O., Aboderin, A. O., \& Huraina, H. A. (2011). Hepatitis B viral markers in surface antigen negative blood donors: the need to look beyond antibody negativity. West African Journal of Medicine. 30:292-295.

27. Mustapha, S. K., \& Jibrin, Y. B. (2014). The prevalence of hepatitis B surface antigenaemia in patients with human immunodeficiency virus (HIV) infection in Gombe, Nigeria. Annuals of African Medicine, 3:10-12. 